\title{
Himatanthus bracteatus (A. DC.) Woodson (Apocynaceae): phenology, morphology, and floral biology of a species endemic to the Atlantic Forest ${ }^{1}$
}

\author{
Rejane Martins Pugas², Joicelene Regina Lima da $\mathrm{Paz}^{3}$, Edinaldo Luz das Neves ${ }^{4}$ and \\ (i)Camila Magalhães Pigozzo 2,5
}

Received: 1.05.2017; accepted: 6.06.2018

\begin{abstract}
Himatanthus bracteatus (A. DC.) Woodson (Apocynaceae): phenology, morphology, and floral biology of a species endemic to the Atlantic Forest). Janaúba, Himatanthus bracteatus (A. DC.) Woodson is a species native to the Atlantic Forest and restricted to the northeastern and southeastern regions of Brazil, and has potential as ornamental or in the recovery of degraded areas. Considering that the information about its reproductive mechanisms is scarce, this study aimed to describe the aspects of the phenology, morphology, and floral biology of $\mathrm{H}$. bracteatus in an urban remnant of Atlantic Forest in Salvador (State of Bahia). Monthly, from August 2008 to August 2009, we recorded the intensity of the phenophases (flowering, fruiting, and budding), aspects of the morphology, and floral development in 15 adult individuals. Flowers and fruits occurred almost throughout the month; the flowering peak was associated with the rainy season, and the seeds dispersion occurred through the wind. Flowers are white, bisexual, cleistogamous and remain open for more than 24 hours, suggesting a more elaborate pollination process, dependent on nocturnal and diurnal specialist visitors for their reproduction.
\end{abstract}

Keywords: floral events, tropical reforestation, janaúba, floral morphology, ornamental potential

RESUMO - (Himatanthus bracteatus (A. DC.) Woodson (Apocynaceae): fenologia, morfologia e biologia floral de uma espécie endêmica da Mata Atlântica). A janaúba, Himatanthus bracteatus (A. DC.) Woodson é uma espécie nativa da Mata Atlântica, restrita às regiões Nordeste e Sudeste do Brasil, que apresenta potencial paisagístico e de uso na recuperação de áreas degradadas. Considerando que informações acerca dos seus mecanismos reprodutivos são escassos, este estudo objetivou descrever os aspectos fenológicos e a morfologia e biologia floral de $H$. bracteatus em um remanescente urbano de Salvador (BA). Mensalmente, entre agosto de 2008 e agosto de 2009, foram registrados a intensidade das fenofases (floração, frutificação e brotamento), aspectos relativos à morfologia e ao desenvolvimento floral em 15 indivíduos adultos. Flores e frutos ocorreram praticamente ao longo de todos os meses, com o pico da floração associado ao período chuvoso, e a dispersão de sementes ocorre pelo vento. As flores são brancas, bissexuais, cleistogâmicas e com duração de abertura superior a 24 horas, sugerindo um processo de polinização mais elaborado, dependente de visitantes especializados de hábito noturno ou diurno para a sua reprodução.

Palavras-chave: eventos florais, reflorestamento, janaúba, morfologia floral, potencial ornamental

\section{Introduction}

The Atlantic Forest biome is currently reduced to less than $7 \%$ of its original area (Varjabedian 2010). Its remnants became landscapes surrounded by urban centers, agricultural, and industrial areas (Ayris et al. 2005, Sarmento \& Villela 2010), which form a mosaic of habitats of several sizes, around small islands or isolated forest fragments (Primack \& Rodrigues 2001). This way, ecological processes,

1. Parte da Monografia do primeiro Autor

2. Centro Universitário Jorge Amado, Avenida Luiz Viana Filho, 6775, Campus Paralela, 41745-130 Salvador, BA, Brasil

3. Universidade Estadual de Feira de Santana, Departamento de Ciências Biológicas, Laboratório de Entomologia, Avenida Universitária, s/n, Cidade Universitária, 44031-460 Feira de Santana, BA, Brasil

4. Centro Universitário Jorge Amado, Rua Miguel Calmon, 42, Edifício São Paulo, Campus Comércio, Prédio IV, $40015-060$ Salvador, BA, Brasil

5. Corresponding author: camilapigozzo@gmail.com 
such as gene flow, carried out between plants through pollination and seed dispersal can be interrupted, jeopardizing the genetic viability of local populations (Gurevitch et al. 2009, Sarmento \& Villela 2010). The reduction in genetic variability increases the chances of species extinction, and also restricts the movement of seeds and pollen, maximizing the endogamy in the population (Charlesworth \& Charlesworth 1987).

Hence, biodiversity conservation represents one of the greatest challenges of this century due to the high level of anthropic disturbances in natural ecosystems (Viana \& Pinheiro 1998, Primack \& Rodrigues 2001). However, many traditional practices for the recovery of degraded areas and reforestation frequently introduce exotic species that promote changes in natural ecosystems (Espíndola et al. 2005), in detriment of native plants. The lack of knowledge about the list of these native plant species and their basic biological information usually justifies this procedure.

With many plant genera popularized in landscaping due to their frequent use (CEAP DESIGNE 2015), the family Apocynaceae s.l. is well represented in the Brazilian flora with 7,600 species of 77 genera (Flora do Brasil 2017). Although its members are distributed nearly all over the world, comprising 357 genera and approximately 5,100 species, this family is particularly diverse in tropical and subtropical regions (Nazar et al. 2013, Endress et al. 2014).

The genus Himatanthus Willd. ex Schult. is restricted to South America (one species occurs in Panamá; Spina 2004), and includes nine species, all present in Brazil (Spina 2015). Their members are trees with woody branches bearing terminal inflorescences and fruits in the shape of relatively curved cylindrical follicles (Spina 2004). Locally known as "janaúba", Himatanthus bracteatus (A. DC.) Woodson (Apocynaceae) is a species endemic to Brazil, typical of the Atlantic Forest, with distribution restricted to the northeastern and southeastern regions (Spina 2015). The tree size, ornamental and odoriferous flowers attractive to insects, and fruits consumed by birds are aspects that make this native species a suitable candidate for use in landscaping and reforestation techniques for degraded areas and environments.

"Janaúba" has a broad spectrum of uses comprising from medicinal, in the treatment of inflammations, veterinary and food supplement, to latex extractivism, which has been acquiring growing importance in the market (Linhares 2010). Hence, studies that provide ecological and reproductive information, which could be used for the management and conservation of this species are necessary. In the face of the lack of information in the specific literature about the species in focus, the main objective of the present study was to investigate aspects of the reproductive biology and phenology of $H$. bracteatus to support its conservation in urban fragments, in particular, the city of Salvador and its metropolitan region.

\section{Material and methods}

Study area - The present study was carried out in an urban remnant of second-growth Atlantic Forest (area of approximately $240 \mathrm{ha}$ ), located at the $19^{\text {th }}$ Hunters Battalion of the Brazilian Army $\left(19^{\circ} \mathrm{BC} ; 12^{\circ} 57^{\prime} 53^{\prime \prime} \mathrm{S}\right.$, $38^{\circ} 27^{\prime} 14^{\prime \prime} \mathrm{W}$ ), at the Cabula neighborhood, Salvador, state of Bahia, Brazil. The climate of the region is classified as Af, according to Köppen classification (1918), warm and humid tropical climate, without a well-defined dry season, with average annual temperatures of $25.3{ }^{\circ} \mathrm{C}$ (Macedo et al. 2007) and an annual rainfall of 2,098.7 $\mathrm{mm}$ (Defesa Civil de Salvador 2015). The months from April to July 2009 were the rainiest, whereas between August 2008 and March 2009 rainfall was lower (figura 1 a).

We picked randomly for the phenological study adult individuals $(n=15)$ on the edge of the forest and monitored them monthly from August 2008 to August 2009. We estimated the intensity of reproductive (open flower, ripe, and immature fruit) and vegetative phenophases (leaf loss and budding) for each individual, following the semiquantitative method proposed by Fournier (1974), with interval categories ranging from 0 to 4 , varying in $25 \%$.

We analyzed floral morphology in the field, where we recorded color and odor emission. We measured depth and width of the corolla tube and flower width $(n=22)$ with a caliper with a precision of $0.01 \mathrm{~mm}$. Based on fresh material fixed in alcohol $70 \%$, we characterized symmetry, corolla form, and the arrangement of the gynoecium and androecium, following Gonçalves \& Lorenzi (2007).

We marked and monitored flower buds $(n=25)$ since pre-anthesis and recorded the time from opening to the senescence of flowers, flower longevity, and morphological alterations during floral anthesis. We carried out two experiments to assess aspects of the reproductive biology: spontaneous self-pollination $(\mathrm{n}=20$ inflorescences) and natural pollination (control; $\mathrm{n}=20$ inflorescences), and considered 
reproductive success fruits whose size was above 1 $\mathrm{cm}$. However, we did not carry out manual pollination tests (xenogamy and geitonogamy) due to the difficulty to access pollen grains and the stigma, as it is a cleistogamous flower with cryptic structures. For the same reasons, we could not carry out tests for stigmatic receptivity and pollen viability. The voucher specimen was deposited in the Radambrasil Herbarium of the Botanical Gardens of Salvador (HRB 56.179).

\section{Results and Discussion}

Individual $H$. bracteatus showed flowers almost throughout the year, with a flowering peak between March and April 2009, which was considered the rainiest period, when over $50 \%$ of individuals were flowering (figura 1). The flowering behavior of the population follows, in synchrony, the high intensity of production of flower buds. In August 2008, the intensity of flower production was minimal (below $2 \%$ ), and in the following months (September to November 2008), which had lower rainfall, there were no flowers open (figura 1).

Spina (2004) suggested that this species flowers and set fruits almost throughout the year, based on herbarium data. However, gaps in flower production in $H$. bracteatus plants, like those observed in the present study, were also reported by Pessoa (2008), in a second-growth forest in Southern Bahia State, with the presence of flowers only from January to Abril, and in July and August. In the literature, the few phenological records of species of this genus mention an annual flowering cycle, of intermediate duration, usually between February and May, such as in Himatanthus obovatus (Müll. Arg.) Woodson var. obovatus (Tannus et al. 2006), Himathantus aff. articulata (Vahl) Woodson (Figueiredo 2008), and Himatanthus aff. lancifolius (Müll.Arg.) Woodson (Pereira et al. 2008).

The immature and ripe fruits are simultaneously present in the same individual. Immature fruits started their development in June 2009, reached the maturation peak between August and November, and were absent between January and May 2009. In contrast, the peak of ripe fruits, fully dry and apt to begin seed dispersal occurred between December 2008 and May 2009. In December 2008, all individuals showed open fruits and dehiscent follicles, dispersing seeds by the wind (anemochory). Fruit production is considered long in other congeneric species, usually
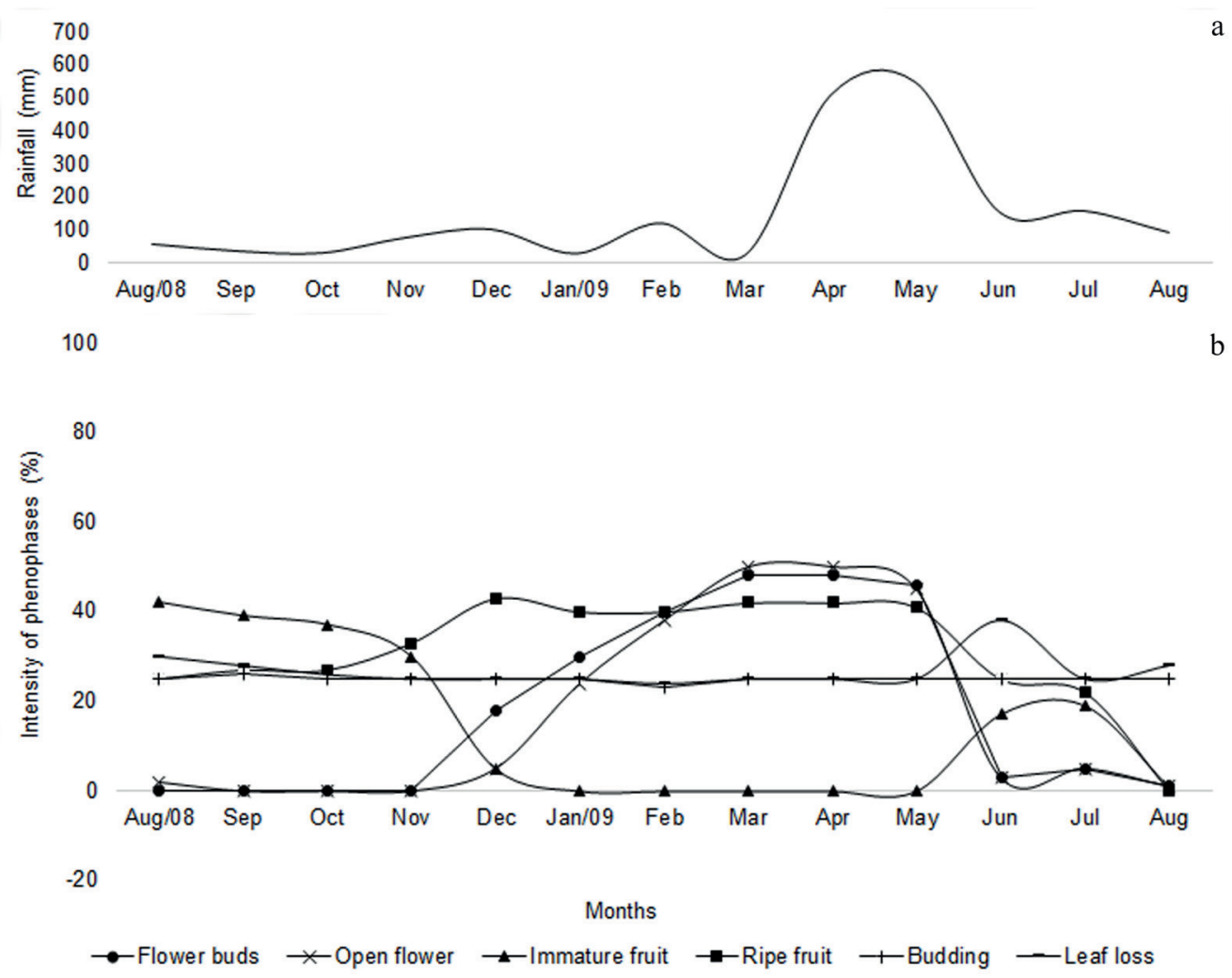

Figure 1. Rainfall (a) and intensity of the reproductive and vegetative phenotypes (b) of Himatanthus bracteatus, in an urban remnant of Atlantic Forest, in Salvador (BA), Northeastern Brazil, from August 2008 to August 2009. Source Rainfall: Civil Defense of Salvador (2014). 
taking place in February and December, with seed dispersal related to anemochory (Pereira et al. 2008). Although the influence of climate factors, such as rainfall and temperature, is reported in many plant groups present in tropical forests (Talora et al. 2000, Stevenson et al. 2008), studies with other Himatanthus species show no correlation with climate data.

Himatanthus bracteatus produces dehiscent, polyspermic follicles, green when immature (figura 2 e) and brown when ripe (figure $2 \mathrm{f}$-g). Seeds are winged, membranous, able to glide, characterizing the anemochory dispersal syndrome (figura $2 \mathrm{~h}$ ), and corroborating other studies on the family Apocynaceae, which usually produces follicles and releases their seeds in the air (Saravy et al. 2003, Amaro et al. 2006, Tannus et al. 2006, Freitas 2008, Figueiredo 2008, Pereira et al. 2008, Pessoa 2008, Silva \& Rodal 2009, Marangon et al. 2010).

There was overlap between phenophases during the thirteen months sampled. At the same time when fruits were ripening, there were still flowers on individuals, but at a lower intensity (figura 1). In the vegetative phenophases, budding and leaf loss rates remained nearly constant throughout the year (approximately $25 \%$ of intensity), except for July 2009 (38\%) for leaf loss. Such results can suggest that rainfall does not influence vegetative phenophases.

Himatanthus bracteatus are bisexual, arranged in terminal inflorescences forming a cincinnus (figura 2 a). Inflorescences are composed of bracts involving two flower buds and a new bract (figura $2 \mathrm{~b})$. The flower dimensions of diameter $(66.7 \pm$ $11.5 \mathrm{~mm})$ and length $(32.6 \pm 0.53 \mathrm{~mm})$ characterize it as typically hypocrateriform. The corolla tube is internally hairy and externally glabrescent; it displays white petals and yellow fauces. Flowers are pentamerous, actinomorphic, dichlamydeous, and cleistogamous. Regarding reproductive structure, there is one bilocular half-inferior ovary, and the stigma (figura $3 \mathrm{~b}$ ) produces a viscous substance comparable to a whitish odorless mucilage, deposited above the stigma. The androecium has five stamens, and five dorsifixed anthers with a longitudinal opening (figura 3 a), where we can visualize the presence of herkogamy between reproductive structures.

In $H$. bracteatus flowers, the pentamerous stamens are united, together with the anthers, to the head of the stigma, forming a gynostegium, which protects the gynoecium. Because of that, there is the union of anthers to the head of the style, creating a cone located in the center of the floral tube. The presence of this wrapping, the gynostegium, is very common in members of the family Apocynaceae (Judd et al. 2009), which was corroborated in studies with Cryptostegia madagascariensis Bojer ex Decne (Vieira et al. 2004), Peltastes peltaltus (Vell.) Woodson (Tostes et al. 2003), Prestonia coalita (Vell.)
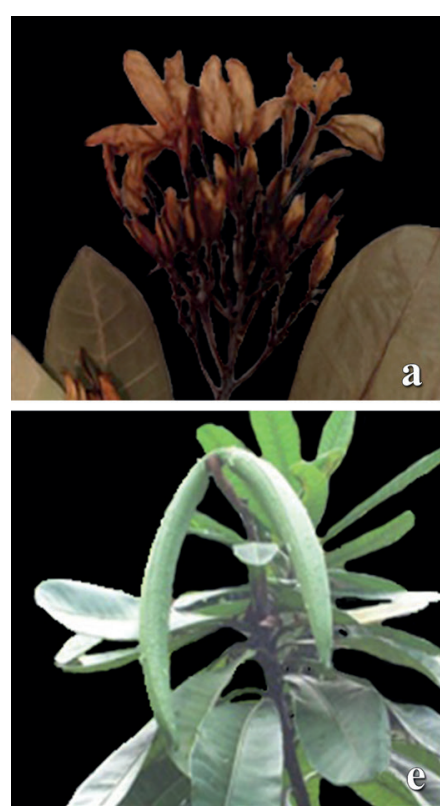
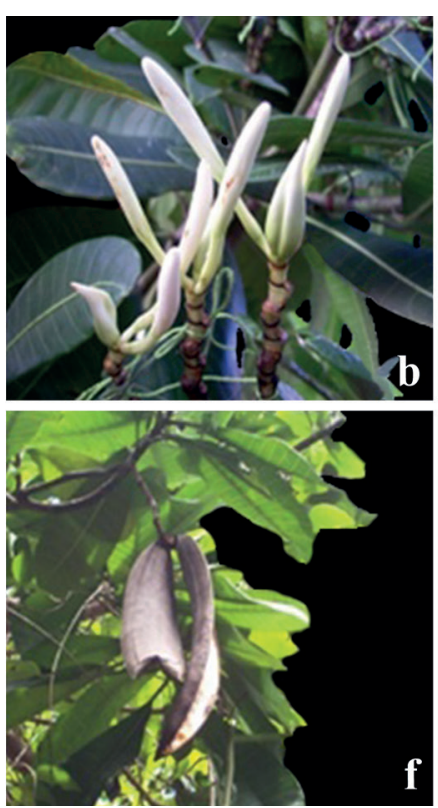
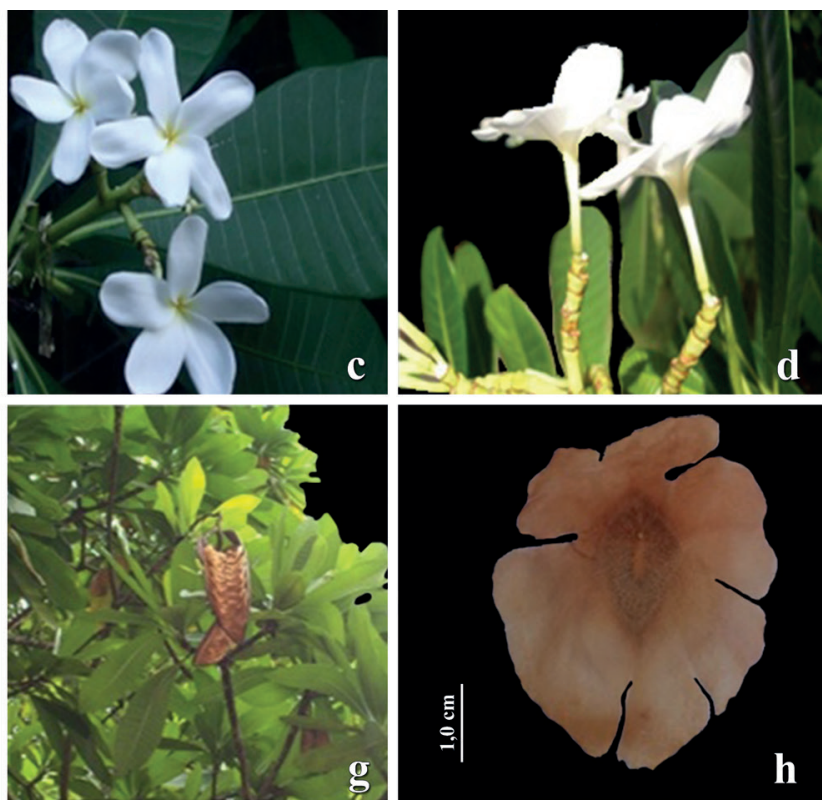

Figure 2. Himatanthus bracteatus. a. Exsiccata, evidencing the terminal inflorescence. b. Flower buds and bracts. c. Pentamerous white flowers with yellow fauces. Photo: Wilton Gonçalves (2008). d. Hypocteriform-shaped flower. Photo: Wilton Gonçalves (2008). e. Immature follicle. f. Dehiscent ripe fruits. g. Ripe fruit with seeds apt for anemochorous dispersal. h. Winged seed, membranaceous, characteristic of anemochorous dispersal. 


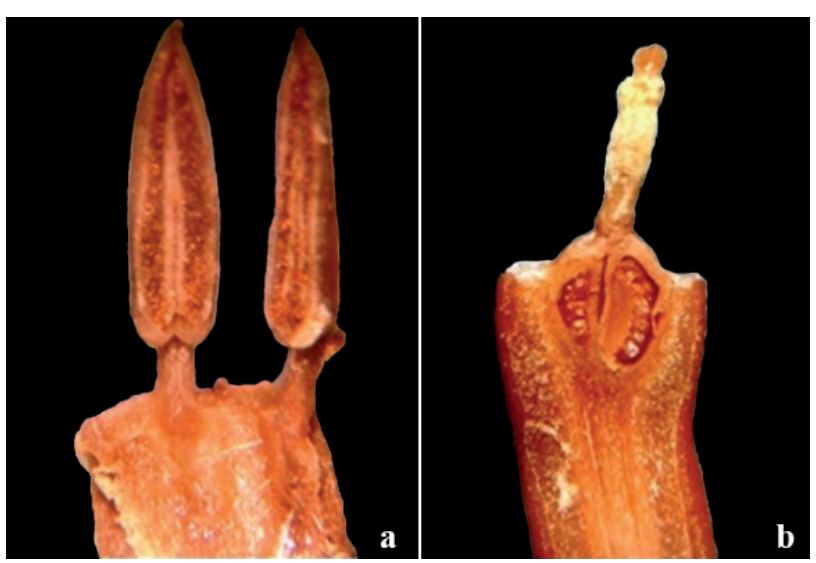

Figure 3. Reproductive structures of Himatanthus bracteatus. a. Anthers with a longitudinal opening. b. Stigma, bilocular semiinferior ovary. Photos: Camilla Reis (2008).

Woodson (Franco 1991), and Prestonia riedelii (Müll. Arg.) Markgr. (Franco 1991). In these studies, the authors observed that there are only small orifices, alternate between stamens, which give access to the inside of the floral tube.

According to Schlindwein et al. (2004), this unusual arrangement of flowers increases floral complexity and enables the formation of a particular pollination apparatus, in which the pollen grains are deposited onto the insect's mouthparts, which are inserted in the same floral tube. This way, later, when these insects visit the flowers, the pollen grains are transferred accidentally to the receptive part of the stigma, which can induce the plant pollination. In Apocynaceae, flowers are reported to be complex with highly specialized pollination mechanisms, such as the secondary presentation of pollen and strong herkogamy (Araújo et al. 2011). In synchrony with the specialization of floral morphological mechanisms, pollinators reported are also specialized, with records of bees (Lopes \& Machado 1999, Raju et al. 2005, Araújo et al. 2011) and moths (Schlindwein et al. 2004, Darrault \& Schlindwein 2005).

However, the main pollinators of the genus Himatanthus are Sphingidae moths, with nocturnal visits to the flowers, which are mostly white, tubular, and odoriferous (Schlindwein et al. 2004, Darrault \& Schlindwein 2005). In addition, there are few studies on the reproductive and pollination mechanisms of most species of the genus (Linhares 2010), probably because of difficulties associated with the long duration of flowers (that could be longer than $24 \mathrm{~h}$ ) and the size (height) of individuals that can restrict the handling of experiments and collection of flower visitors.
In $H$. bracteatus inflorescences, flowers begin to open from the periphery to the center. When the bracts that involve the two flower buds and a new bract open, they stimulate the anthesis of the oldest flower bud, and, then, the anthesis of the younger one. After the opening of the bract, the development of the inflorescence opening continues (figure $4 \mathrm{a}-\mathrm{f}$ ). Young buds are greenish at the beginning of budding and become white when ripe. Our observations corroborate those of Gomes \& Cavalcanti (2001), recorded in nine species of the genus Aspidosperma Mart. \& Zucc. (Apocynaceae).

In the pre-anthesis, flower buds exhibited fused petals and opened spirally, as described by Vieira et al. (2004), in other Apocynaceae, C. madagascariensis. Flower buds grew per day, on average, $4.0 \pm 0.56 \mathrm{~mm}$, reaching the maximum size of $4.6 \mathrm{~mm}$, on average, and varying between $5.4 \mathrm{~mm}$ and $5.7 \mathrm{~mm}$. This stage was the establishment of the beginning of the anthesis. H. bracteatus flowers began anthesis around 11:30, with the movement of petal despiralization and finished their opening around 19:00 (figure 4 a-f). Flower longevity is $24 \mathrm{~h}$ when the corolla abscission occurs. These characteristics were also observed and described in detail by Vieira et al. (2004).

We did not observe the formation of fruits in experiments of spontaneous self-pollination $(n=20)$. In natural pollination (control; $\mathrm{n}=26$ ), only some flowers of the inflorescence set fruits $(n=08)$, and we considered reproductive success follicles above $1 \mathrm{~cm}$. Although we did not test stigmatic receptivity and pollen viability, we can infer that $H$. bracteatus is self-incompatible based on spontaneous selfpollination data and the results obtained by Franco (1991), Vieira et al. (204), and Schlindwein et al. (2004) while studying species of the same family and one species of the same genus. Hence, we suggest testing this hypothesis in further studies with this species though complementary experiments of pollen viability, stigmatic receptivity, and fruit set viability in cross-pollination tests (xenogamy and geitonogamy).

This possible self-incompatibility potentialize the pollination dependence of these plants on animals, as they are indispensable for crosspollination species and the increment in gene flow, through genetic variability. Furthermore, when we consider that $H$. bracteatus is a native species with typical occurrence in second-growth forest vegetation (Linhares et al. 2011), resulting from an advanced natural regeneration process, the permanence of 

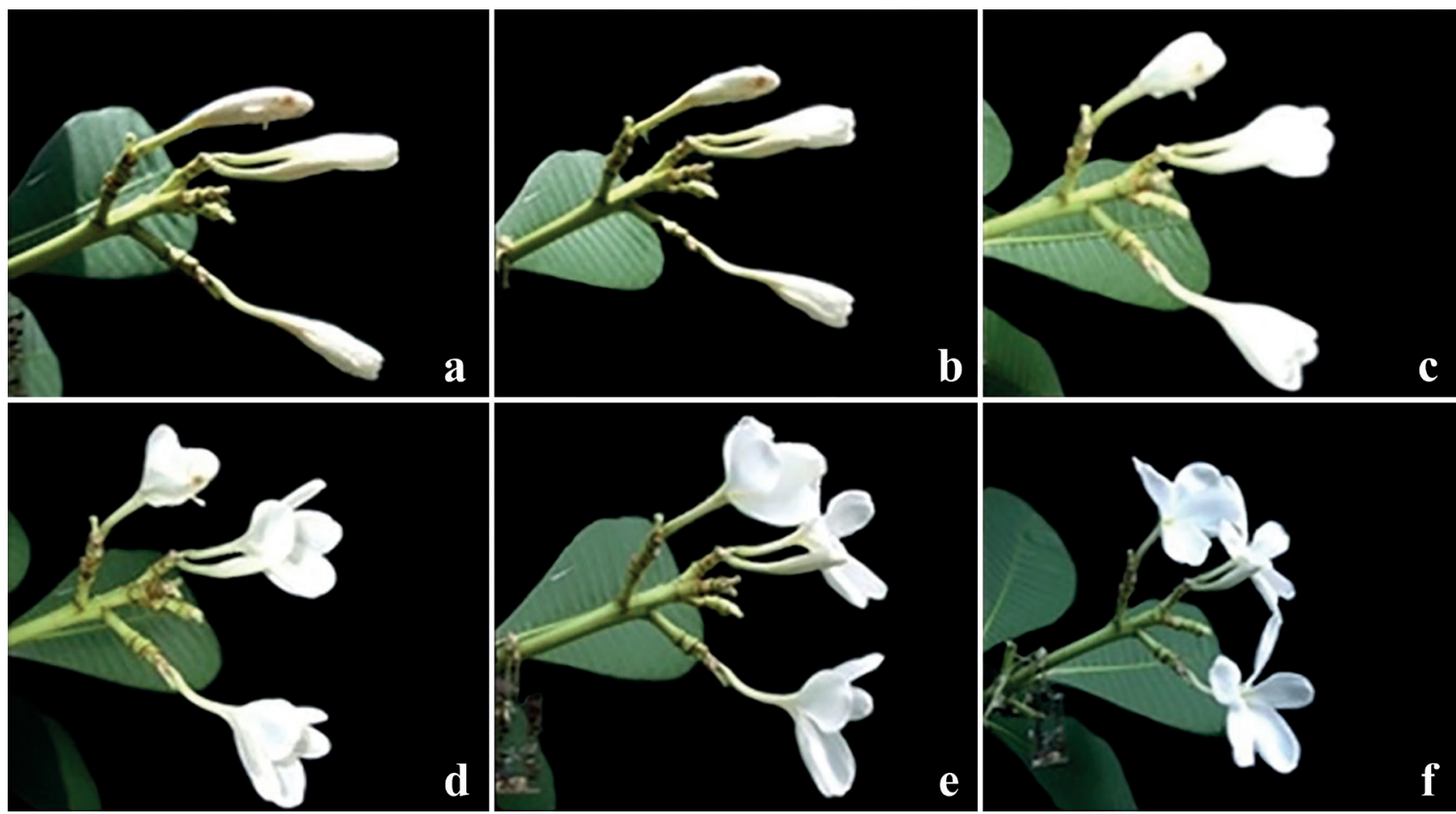

Figure 4. Sequence of a flower opening in Himatanthus bracteatus throughout the day. a. Beginning of the anthesis, around 11:30. b. Sequence of a flower opening around 12:30. c. Sequence of a flower opening around 13:30. d. Sequence of a flower opening around 14:30. e. Sequence of a flower opening around 15:30. f. Flower almost fully open around 16:30 (note the spiral movement of petals).

pollinating animals in these habitats is crucial for pollination, one of the key ecological services for the maintenance and conservation of ecosystems (Daily 1997).

Himathantus bracteatus is endemic to the Atlantic Forest, with a distribution restricted to nine states in the northeastern and southeastern regions of Brazil. With the presence of flowers and fruits almost throughout the year, the peak of flowering intensity can be associated with the rainy season and the dispersal of winged seeds, related to the wind. The presence of bisexual, cleistogamous, and herkogamous flowers with peculiar floral biology, as it is typical of Apocynaceae, restrict the access to the nectary to flower visitors with long mouthparts, through the arrangement of small alternate orifices between stamens, which increases flower complexity and its dependence on specific pollinators. Flower longevity surpasses $24 \mathrm{~h}$, increasing the chances of pollination by nocturnal and diurnal animals. However, as these organisms (plant and animals) are present in habitats of second-growth forests and urban remnants, they are subjected to the effects of fragmentation and habitat loss, which decreases potentially the possibility of meeting, and consequently, reproductive success.

\section{Acknowledgments}

The authors thank the leading members of the $19^{\text {th }}$ Hunters Battalion of the Brazilian Army - Pirajá Regiment - for granting us the permit to research the study area, in particular, the military and collaborators who helped to perform the study in the field. MSc. Erivaldo P. Queiroz (Botanical Gardens of Salvador, State of Bahia) made the botanical identification. Camilla Reis and Wilton Gonçalves made photographic records, and Marília Paz, photographic adjustments.

\section{Literature cited}

Amaro, M.S., Medeiros Filho, S., Guimarães, R.M. \& Teófilo, E.M. 2006. Morfologia de frutos, sementes e de plântulas de Janaguba (Himatanthus drasticus (Mart.) Plumel - Apocynaceae. Revista Brasileira de Sementes 28: 63-71.

Araujo, L.D.A., Quirino, Z.G.M. \& Machado, I.C. 2011. Fenologia reprodutiva, biologia floral e polinização de Allamanda blanchetii, uma Apocynaceae endêmica da Caatinga. Revista Brasileira de Botânica 34: 211-222.

Ayris, J.M., Fonseca, G.A.B., Rylands, A.B., Queiroz, H.L., Pinto, L.P., Masterson, D. \& Cavalcante, R.B. 2005. Os corredores ecológicos das florestas tropicais do Brasil. Sociedade Civil Mamirauá, Belém-PA. 
CEAP DESIGN - Centro de Estudos Ambientais e Paisagísticos Pesquisa botânica e prática profissional. 2015. Available in http://www.ceapdesign.com.br/ familias_botanicas/apocynaceae.html (access in 29-I-2015).

Charlesworth, D. \& Charlesworth, B. 1987. Inbreeding depression and its evolutionary consequences. Annual Review of Ecology, Evolution, and Systematics 18: $237-268$.

Daily, G.C. 1997. Introduction: what are ecosystem services? In: G.C. Daily (ed.). Natures's services: societal dependence on natural ecosystems. Washington D.C: Island Press, pp. 1-10.

Darrault, R.O. \& Schlindwein, C. 2005. Limited fruit production in Hancornia speciosa (Apocynaceae) and pollination by nocturnal and diurnal insects with long mouth parts. Biotropica 37: 381-388.

Defesa Civil de Salvador. 2015. Available in http://www. defesacivil.salvador.ba.gov.br/index.php?option=com content\&task=view\&id=43\&Itemid=54 (access in 29-I-2015).

Endress, M.E., Liede-Schumann, S., \& Meve, U. 2014. An updated classification for Apocynaceae. Phytotaxa 159: 175-194.

Espíndola, M.B., Bechara, F.C., Bazzo, M.S. \& Reis, A. 2005. Recuperação ambiental e contaminação biológica: aspectos ecológicos e legais. Biotemas 18: 27-38.

Figueiredo, P.S. 2008. Fenologia e estratégias reprodutivas das espécies arbóreas em uma área marginal de cerrado, na transição para o semi-árido no nordeste do Maranhão, Brasil. Revista Trópica 2: 8-22.

Flora do Brasil 2020 (em construção). 2017. Apocynaceae. Jardim Botânico do Rio de Janeiro. Available in http:// floradobrasil.jbrj.gov.br/reflora/floradobrasil/FB48 (access in 14-IX-2017).

Fournier, L.A. 1974. Un metodo cuantitativo para la medición de caracteristicas fenológicas en arboles. Turrialba 24: 422-423.

Franco, A.L.M. 1991. Biologia floral de duas espécies sincronopátricas de Prestonia (Apocynaceae). Dissertação de Mestrado. Instituto de Biologia da Universidade Estadual de Campinas, São Paulo.

Freitas, A.D.D. 2008. Aspectos tecnológicos e morfoanatômicos de sementes maduras, plântulas e plantas jovens de Aspidosperma spruceanum Benth. ex Mull. ARG. (Apocynaceae). Dissertação de Mestrado. Universidade Federal Rural da Amazônia e do Museu Paraense Emílio Goeldi, Belém.

Gomes, S.M. \& Cavalcanti, T.B. 2001. Morfologia floral de Aspidosperma Mart. \& Zucc. Apocynaceae. Acta Botânica Brasileira 15: 73-88.

Gonçalves, E.G. \& Lorenzi, H. 2007. Morfologia Vegetal: organografia e dicionário ilustrado de morfologia das plantas vasculares. São Paulo, Instituto Plantarum de Estudos da Flora.
Gurevitch, J., Scheiner, S.M. \& Fox, G.A. 2009. Ecologia vegetal. 2.ed. Porto Alegre, Artmed.

Judd, W.S., Campbell, C.S., Kellogg, E.A., Stevens, P.F. \& Donoghue, M.J. 2009. Sistemática vegetal: um enfoque filogenético. Artmed, Porto Alegre.

Linhares, J.F.P.L. 2010. Sustentabilidade sócio-ambiental da extração de janaúba (Himatanthus Willd. ex Schult.) no município de Alcântara, MA, Brasil. Dissertação de Mestrado, Universidade Federal do Maranhão, São Luís.

Linhares, J.F.P., Pinheiro, C.U.B., Ming,L.C., Rodrigues, M.I.A. \& Ferreira, A.B. 2011. Ambientes de ocorrência e flora acompanhante do gênero Himatanthus em Alcântara, Maranhão, Brasil. Revista Brasileira de Plantas Medicinas 13: 550-558.

Lopes, A.V. \& Machado, I.C. 1999. Pollination and reproductive biology of Rauvolfia grandiflora (Apocynaceae) secondary pollen presentation, herkogamia and self-incompatibility. Plant Biology 1: 547-553.

Macedo, T. S., Fernandes, L. L., Silva, D. F., Varjão, A. S., Neves, A. S. \& Pigozzo, C. M. 2007. Comparação florística entre um fragmento de Mata Atlântica e ambientes associados (Restinga e Manguezal) na cidade de Salvador, Bahia. Revista Virtual Candombá 3: $138-148$.

Marangon, G.P., Cruz, A.F., Barbosa, W.B., Loureiro, G.H. \& Holanda, A.C. 2010. Dispersão de sementes de uma comunidade arbórea em um remanescente de Mata Atlântica, Município de Bonito, PE. Revista Verde 5: 80-87.

Nazar, N., Goyder, D.J., Clarkson, J.J., Mahmood, T., Chase, A.M.W. 2013. The taxonomy and systematics of Apocynaceae: where we stand in 2012. Botanical Journal of the Linnean Society 171: 482-490.

Pereira, T.S., Costa, M.L.M.N., Moraes, L.F.D. \& Luchiari, C. 2008. Fenologia de espécies arbóreas em Floresta Atlântica da Reserva Biológica de Poço das Antas, Rio de Janeiro, Brasil. Iheringia (Série Botânica) 63: 329-339.

Pessoa, M.S. 2008. Comparação da comunidade arbórea e fenologia reprodutiva de duas fisionomias em floresta Atlântica no sul da Bahia, Brasil. Dissertação de Mestrado, Universidade Estadual de Santa Cruz, Ilhéus.

Primack, R.B. \& Rodrigues, E. 2001. Biologia da conservação. Efraim Rodrigues, Londrina.

Raju, A.J.S., Zafar, R. \& Rao, S.P. 2005. Floral device for obligate selfing by remote activity and anemochory in Wrightia tinctoria (Roxb.) R. Br. (Apocynaceae). Current Science 88: 1378-1380.

Saravy, F.P., Freitas, P.J., Lage, M.A., Leite, S.J., Braga, L.F. \& Sousa, M.P. 2003. Síndrome de dispersão em estratos arbóreos em um fragmento de floresta ombrófila e densa em Alta Floresta - MT. Revista do Programa de Ciências Agro-Ambientais 2: 1-12.

Sarmento, M.B. \& Villela, F.A. 2010. Sementes de espécies florestais nativas do Sul do Brasil. Informativo Abrates 20: 39-44. 
Schlindwein, C., Darrauli, R.O. \& Grisi, T. 2004. Reproductive strategies in two sphingophilous apocynaceous trees attracting pollinators through nectar or deceit. Fangmeier, pp. 215-227.

Silva, M.C.N.A. \& Rodal, M.J.N. 2009. Padrões das síndromes de dispersão de plantas em áreas com diferentes graus de pluviosidade, PE, Brasil. Acta Botânica Brasileira 23: 1040-1047.

Spina, A.P. 2004. Estudos taxonômicos, micro-morfológicos e filogenéticos do gênero Himatanthus Willd. ex Schult. (Apocynaceae: Rauvolfioideae - Plumerieae). Tese de Doutorado. Instituto de Biologia da Universidade Estadual de Campinas, São Paulo.

Spina, A.P. 2015. Himatanthus In: Lista de Espécies da Flora do Brasil. Jardim Botânico do Rio de Janeiro. Available in http://reflora.jbrj.gov.br/jabot/floradobrasil/ FB4620 (access in 29-I-2015).

Stevenson, P.R., Castellanos, M.C., Cortés, A.I. \& Link, A. 2008. Flowering patterns in a seasonal tropical lowland forest in western Amazonia. Biotropica 40: 559-567.

Talora, D.C. \& Morellato, L.P.C. 2000. Fenologia de espécies arbóreas em floresta de planície litorânea do sudeste do Brasil. Revista Brasileira de Botânica 23:13-26.
Tannus, J.L.S., Assis, M.A. \& Morellato, L. P. 2006. Fenologia reprodutiva em campo sujo e campo úmido numa área de cerrado no sudeste do Brasil, Itirapina-SP. Biota Neotropica 6: 1-27.

Tostes, R.B., Vieira, M.F. \& Campos, L.A.O. 2003. Polinização de Peltastes peltatus (Vell.) Woodson (Apocynoideae, Apocynaceae) por abelhas euglossíneas. In: G.A.R. Melo \& I. Alves-dos-Santos (eds.). Apoidea Neotropica: homenagem aos 90 anos de Jesus Santiago Moure, Editora UNESC, Criciúma, pp.297-302.

Varjabedian, R. 2010. Lei da Mata Atlântica: Retrocesso ambiental. Estudos avançados [online]. 24: 147160. Available in http://dx.doi.org/10.1590/S010340142010000100013 (access in 15-II-2016).

Viana, V.M. \& Pinheiro, L.A.F.V. 1998. Conservação da biodiversidade em fragmentos florestais. Série Técnica IPEF 12 32: 25-42.

Vieira, M.F., Leite, M.S.O, Grossi, J.A.S. \& Alvarenga, E.M. 2004. Biologia reprodutiva de Cryptostegia madagascariensis Bojer ex Decne. (Periplocoideae, Apocynaceae), espécie ornamental e exótica no Brasil. Bragantia 63: 325-334. 